\title{
Diaphragmatic fenestration for resistant pleural effusions after the Fontan operation
}

\author{
Sachin Talwar, MCh, Shiv Kumar Choudhary, MCh, Shivaprasad Babu Mukkannavar, MCh, and \\ Balram Airan, MCh, New Delhi, India
}

Persistent pleural effusion and chylothorax are major sources of morbidity after univentricular repair. ${ }^{1,2}$ Sometimes these fail to respond to prolonged conservative treatment and demand surgical intervention. We adopted a strategy of diaphragmatic fenestration in such patients and report the technique and results. ${ }^{3,4}$

\section{CLINICAL SUMMARY}

We performed this procedure in 4 patients (Table 1). Before undertaking this procedure, structural and functional abnormalities in the Fontan pathway were ruled out by appropriate investigations. The procedure was carried out on the side of the significant effusion and on both sides in patient 1 . The procedure is described as follows: A limited posterolateral thoracotomy is performed through the fifth

From the Cardiothoracic Center, All India Institute of Medical Sciences, New Delhi, India.

Disclosures: Authors have nothing to disclose with regard to commercial support.

Received for publication May 3, 2011; revisions received July 12, 2011; accepted for publication July 19, 2011; available ahead of print Aug 16, 2011.

Address for reprints: Sachin Talwar, MCh, Department of Cardiothoracic and Vascular Surgery, All India Institute of Medical Sciences, New Delhi -110029, India (E-mail: sachintalwar@hotmail.com).

J Thorac Cardiovasc Surg 2012;143:244-5

$0022-5223 / \$ 36.00$

Copyright $($ c 2012 by The American Association for Thoracic Surgery doi:10.1016/j.jtcvs.2011.07.030 intercostal space, and the dome of diaphragm is exposed. For the left-sided effusions, the thoracic duct is ligated first. After identifying the dome of the diaphragm, an area of the diaphragm free of nerves and vessels is identified, and using Babcock forceps, it is lifted up from the underlying liver or spleen depending on the side. A $4 \times 3$-cm opening is then cut out in the dome of the diaphragm, taking care not to injure the underlying structures. In patient 1 , we elected to suture an appropriately sized polypropylene mesh to the margins of this defect. However, we currently prefer to use an appropriately sized polytetrafluoroethylene (Gore-Tex; WL Gore and Associates, Flagstaff, Ariz) patch. Multiple fenestrations are made in this patch using a 4-mm standard aortic punch. This fenestrated patch is then sutured to the margins of the defect in the diaphragm using a continuous 4-0/5-0 polypropylene suture (Figure 1). After placing a chest tube, the chest is closed in the usual manner. No inotropic support usually is required, and the patients are extubated soon after arrival in the intensive care unit. The chest tube output is monitored, and the abdominal girth is measured to rule out the development of ascites. Once the drain output has become nil for at least 48 hours, the chest tube is removed and the patient is discharged with advice to repeat the chest x-ray at 1 week, 1 month, 3 months, and yearly intervals. The doses of diuretics and vasodilators are adjusted as needed.

TABLE 1. Summary of patients undergoing diaphragmatic fenestration after univentricular repair

\begin{tabular}{|c|c|c|c|c|c|c|c|}
\hline SI no. & $\begin{array}{l}\text { Age }(\mathrm{y}) / \mathrm{sex} / \\
\text { weight }(\mathrm{kg})\end{array}$ & Diagnosis & Procedure & $\begin{array}{c}\text { Drainage before } \\
\text { diaphragmatic } \\
\text { fenestration }\end{array}$ & $\begin{array}{c}\text { Interval between } \\
\text { initial surgery and } \\
\text { diaphragmatic } \\
\text { fenestration }\end{array}$ & $\begin{array}{c}\text { Chest tube drainage } \\
\text { after diaphragmatic } \\
\text { fenestration }\end{array}$ & Procedure \\
\hline 1 & $12 / \mathrm{M} / 30$ & $\begin{array}{c}\text { CTGA, VSD, PS, } \\
\text { RV hypoplasia }\end{array}$ & $\begin{array}{c}\text { Fenestrated lateral } \\
\text { tunnel TCPC }\end{array}$ & $\begin{array}{l}400-500 \mathrm{~mL} / \mathrm{d} \\
\text { for } 6 \mathrm{wk}\end{array}$ & $6 \mathrm{wk}$ & Removed $7 \mathrm{~d}$ after DF & $\begin{array}{l}\text { Bilateral DF with } \\
\text { thoracic duct } \\
\text { ligation on left* }\end{array}$ \\
\hline 2 & $5 / \mathrm{M} / 12$ & TA, VSD, PS & $\begin{array}{c}\text { Fenestrated lateral } \\
\text { tunnel TCPC }\end{array}$ & $\begin{array}{l}1100 \mathrm{~mL} \text { on } \\
\text { postoperative } \\
\text { day } 60 \dagger\end{array}$ & $60 \mathrm{~d}$ & Removed $7 \mathrm{~d}$ after DF & $\begin{array}{l}\text { Thoracic duct } \\
\text { ligation + left DF }\end{array}$ \\
\hline 3 & $11 / \mathrm{F} / 30$ & $\begin{array}{l}\text { TOF, } \\
\text { TV hypoplasia }\end{array}$ & $\begin{array}{c}\text { Extracardiac Fontan } \\
\text { completion (BDG } \\
8 \text { y previously) }\end{array}$ & $\begin{array}{c}>600 \mathrm{~mL} / \mathrm{d} \text { on } \\
\text { right side }\end{array}$ & $25 \mathrm{~d}$ & Removed $8 \mathrm{~d}$ after DF & $\begin{array}{l}\text { 1. Fenestration of } \\
\text { conduit on day } 10 \\
\text { 2. DF on day } 25\end{array}$ \\
\hline 4 & $5 / \mathrm{M} / 10$ & SV, PS & $\begin{array}{c}\text { Fenestrated lateral } \\
\text { tunnel TCPC }\end{array}$ & $\begin{array}{l}>500 \mathrm{~mL} / \mathrm{d} \text { for } \\
3 \mathrm{wk}\end{array}$ & $21 \mathrm{~d}$ & Removed $5 \mathrm{~d}$ after DF & $\begin{array}{l}\text { Right DF } 21 \mathrm{~d} \text { after } \\
\text { TCPC }\end{array}$ \\
\hline
\end{tabular}

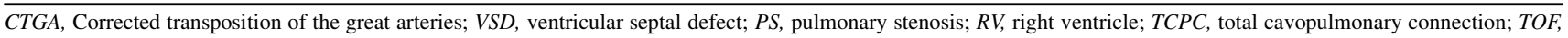
tetralogy of Fallot; $S V$, single ventricle; $D F$, diaphragmatic fenestration; $T A$, tricuspid atresia; $T V$, tricuspid valve. *Polypropylene mesh used. $\nmid$ This patient was readmitted on day 60 after TCPC with massive left pleural effusion. After a trial of conservative treatment for 10 days, he underwent bilateral DF with thoracic duct ligation. 


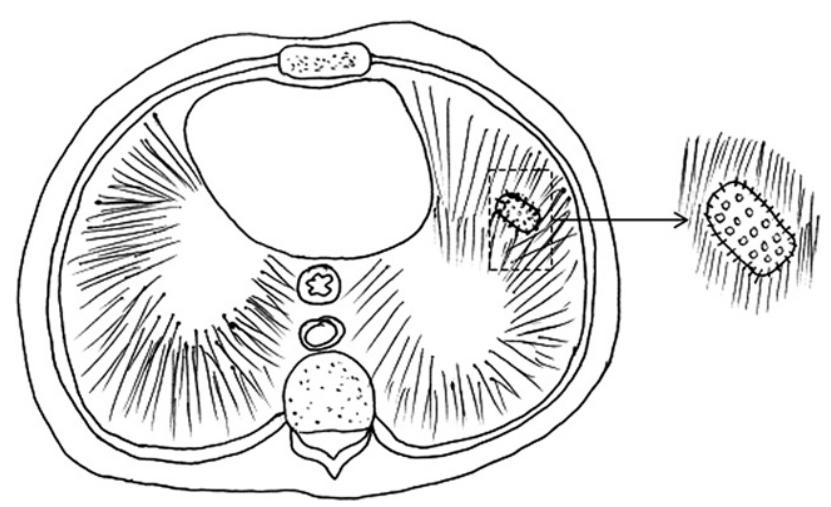

FIGURE 1. Diaphragmatic fenestration technique. An appropriately sized polytetrafluoroethylene (Gore-Tex; WL Gore and Associates, Flagstaff, Ariz) patch is sutured to the margins of the surgically created defect in the diaphragm after making multiple punch holes in the patch using a 4-mm aortic punch.

\section{DISCUSSION}

Our experience with 4 patients as listed in Table 1 clearly indicates the usefulness of this technique in managing resistant pleural effusions after univentricular repair. After this procedure, the fluid from the pleural space enters the peritoneal cavity, where it is easily reabsorbed because of a larger surface area available for absorption. This significantly reduces the amount of pleural drainage, allowing the chest drain to be removed and the patient to be discharged. We have observed no significant ascites in these patients. We also believe that once the pleural effusion is limited, the Fontan dynamics may improve further, and this may limit the development of new effusions.

An alternative would be to perform only a thoracic duct ligation on the left side for a persistent chylothorax. However, it has been our observation that on thoracotomy, there is often diffuse ooze from the pleural surface, and mere ligation of the thoracic duct alone may not be sufficient. ${ }^{4}$ In these situations, diaphragmatic fenestration is a useful adjunct. An advantage of this technique over the use of a pleuroperitoneal shunt is that the multiple large holes in the patch are unlikely to get blocked compared with the former. ${ }^{5}$ In patient 1 , we used a polypropylene mesh, and although there was no evidence to suggest this, in the remaining patients we preferred to use a polytetrafluoroethylene (Gore-Tex) patch with multiple 4-mm holes because we thought the larger holes in the latter were unlikely to be blocked.

\section{CONCLUSIONS}

We observed no complications related to this technique and procedure, and there were no adverse clinical manifestations of any unfavorable effect on the mechanics of the diaphragm. Obviously, if it were to affect the diaphragmatic function unfavorably, the effusions would worsen because patients undergoing univentricular palliation respond adversely to impaired diaphragmatic function. However, the favorable effects of this procedure, if any, on diaphragm function are unknown. We hope that as the procedure is adopted widely with longer follow-up and studied in more detail, more questions will be answered.

\section{References}

1. Milonakis M, Chatzis AC, Giannopoulous NM, Contrapuris C, Bobos D, Kirvasillis GV, et al. Etiology and management of chylothorax following pediatric heart surgery. J Card Surg. 2009;24:369-73

2. Talwar S, Agarwala S, Mittal CM, Choudhary SK, Airan B. Pleural effusions in children undergoing cardiac surgery. Ann Pediatr Cardiol. 2010;3:58-64.

3. Durairaj M, Sharma R, Choudhary SK, Bhan A, Venugopal P. Diaphragmatic fenestration for resistant pleural effusions after univentricular repair. Ann Thorac Surg. 2002;74:931-2.

4. Talwar S, Choudhary SK, Airan B. Diaphragmatic fenestration for resistan chylothorax. Ann Thorac Surg. 2006;82:767-8.

5. Reich H, Beattie EJ, Harvey JC. Pleuroperitoneal shunt for malignant effusions a one year experience. Semin Surg Oncol. 1993;9:160-2. 